\title{
RISK ASSESSMENT OF EXTREME WEATHER CONDITIONS FOR NUCLEAR POWER PLANTS AT TIDAL RIVERS
}

\section{OCENA RYZYKA SKRAJNYCH WARUNKÓW POGODOWYCH DLA ELEKTROWNI ATOMOWYCH NAD RZEKAMI Z PEYWAMI}

\author{
Heinz-Peter Berg ${ }^{1}$, Matias Krauß ${ }^{1}$ \\ (1) Federal Office for Radiation Protection \\ Willy Brandt-Str. 5, 38226 Salzgitter, Germany \\ e-mails: hberg@bfs.de,mkrauß@bfs.de
}

\begin{abstract}
The effects of flooding on a nuclear power plant site may have a major bearing on the safety of the plant and may result in a common cause failure for safety related systems, such as the emergency power supply systems. For river sites with tidal influences, an extreme flood event - tide combined with storm water level set-up - must be assumed. A storm-tide must be covered with an exceeding frequency of $10^{-4} /$ a. However, the risk assessment regarding the availability of systems and components of a nuclear power plant also includes the situation of extreme low water level of rivers, i. e. below the minimum water level necessary for the supply of the nuclear power plants with cooling water.
\end{abstract}

Keywords: flooding, low water level, hazard analysis

Streszczenie: Powodzie (zalewanie) sa najbardziej rozpowszechnionym naturalnym zagrożeniem w catej Europie, powodujacym często znaczne szkody, gdziekolwiek wystapia. Skutki zalewania terenu, na którym posadowiona jest elektrownia atomowa moga mieć ogromny wpływ na bezpieczeństwo samej elektrowni, jak też na stan systemów 'odpowiedzialnych' za bezpieczeństwo, np. systemów awaryjnego zasilania energia elektryczną. Dla terenów nadrzecznych, gdzie występuja także pływy, należy przyjąć możliwość ekstremalnego zdarzenia, tzn. przypływu połaczonego z podnoszeniem się poziomu wody wskutek sztormu. Należy rozważyć skrajny przypadek przyplywu sztormowego o częstotliwości przekraczajacej $10^{-4} / a$. Trzeba jednak pamiętać, że ocena ryzyka dotyczaca gotowości systemów $i$ elementów elektrowni atomowej do działania obejmuje również przypadek skrajnie niskiego poziomu wody $w$ rzekach, tzn. poniżej poziomu niezbędnego do zaopatrywania elektrowni atomowej w wodę na potrzeby chtodzenia.

Stowa kluczowe: zalewanie, niski poziom wody, analiza zagrożeń 


\section{Introduction}

The effects of flooding on a nuclear power plant site may have a major bearing on the safety of the plant and may lead to a postulated initiating event that is to be included in the plant safety analysis. The presence of water in many areas of the plant may be a common cause failure for safety related systems, such as the emergency power supply systems or the electric switchyard, with the associated possibility of loosing the external connection to the electrical power grid, the decay heat removal system and other vital systems (IAEA, 2003).

Considerable damage can also be caused to safety related structures, systems and components by the infiltration of water into internal areas of the plant, induced by high flood levels caused by the rise of the water table. Water pressure on walls and foundations may challenge their structural capacity. Deficiencies in the site drainage systems and in non-waterproof structures may also cause flooding on the site. This has happened in many cases in the past, with consequent large scale damage documented, and the possibility should be considered in the hazard evaluation and in the design of measures for site protection.

In principle, methods to systematically analyse existing nuclear facilities regarding the adequacy of their existing protection equipment against external flooding can be of deterministic as well as probabilistic nature. However, an international consistent methodology for flood risk analysis would be necessary.

Harsh weather conditions have the potential to cause initiating events in nuclear power plants (NPP). Typical impacts are disturbances of electrical an I\&C equipment as well as adverse effects on the service water system. This implies that harsh weather conditions can actually impair the safety of nuclear power plants. In general, the impact of global climate change on regional meteorological conditions could lead to more hazardous situations. Fortunately, regional-scale climate projections show only moderate changes within the next decades: Whereas during the winter months there is a trend to increased precipitation (including the risk of consequential flooding), less precipitation is expected in summer. Simultaneously heat waves will become more frequent. All in all, on a medium-term scale the hazard due to harsh weather conditions is not expected to increase significantly in Central Europe. 


\section{External flooding in the safety assessment for German nuclear power plants}

The German Incident Guidelines require a determination of a sufficient water level as design-basis and appropriate structural protection measures against this hazard in the design of the plants to avoid radiological consequences for the environment. The adequacy of the protection measures have been shown in the past only on a deterministic basis. The probabilistic safety assessment (PSA) guideline as well as the corresponding technical documents prescribe also probabilistic analyses of external hazards including flooding (Berg and Görtz, 2006).

Appropriate screening procedures are those which on the one hand allow to constrain the complexity of the analysis and, on the other hand, ensure that relevant information are not lost during the screening process and that all safety significant parts of the plant are taken into account.

A graded approach for the extent of a probabilistic assessment in case of external flooding containing deterministic and probabilistic elements has been developed and is described in (FAK PSA, 2005). This approach takes into account site-specific aspects like the NPP grounded level compared with surroundings level and plant-specific aspects such as design with permanent protection measures and prescribed shut down of the plant according to the instructions of the operation manual at a specified water level which is significantly below the level of the design flooding.

In order to calculate the yearly probabilistic of reaching extremely high water levels, an extrapolation of actually measured data is necessary. Appropriate methods and statistics of extremes are now used in a multitude of applications which can be distinguished into different categories (Knochenhauer and Lonker, 2003):

- Methods using yearly maximum/minimum values,

- Methods using threshold values,

- Methods handling dependencies between parameters,

- Extrapolation of measurement series/Log-Persons type III,

- Analysis of historical extreme values.

\section{Extent of the graded approach in PSA for external flooding evaluation}

With respect to the phenomena leading to a flooding event, in principle the sites can be differentiated as follows:

a. Sites on rivers and on inland lakes which are endangered by flood runoffs from the prevailing drainage areas,

b. Coastal sites endangered by flood levels of the ocean, 
c. Sites on tidal rivers endangered both by flood runoffs from the prevailing drainage areas and by flood levels of the ocean.

German nuclear power plants were erected at sites of type a) (without inland lakes) and c). In the first case, where 13 nuclear power plants are located, a high water-level situation may arise from an unfavourable ratio of water inflow to outflow. In the second case, where 4 power plants are located, the coincidence of storm, flooding and high tide is the determining factor.

In the proposed method, the yearly probability of reaching extremely high water levels (in the following named as exceedance frequency) is determined by an extrapolation of actually measured water-level data according to various established methods (Jensen, et al., 2003; Kleemann and Schumann, 2001). The underlying probabilistic considerations and mathematical procedures to calculate the exceedance frequencies are described in (KTA, 2004; Berg et al., 2008).

The graded approach for external flooding can be summarized as given in Table 1 .

Table 1. The graded process for external flooding

\begin{tabular}{|c|c|}
\hline Criterion & Extent of analysis \\
\hline $\begin{array}{l}\text { Flooding of plant site can be practicable } \\
\text { excluded due to the NPP grounded level } \\
\text { compared with surroundings level }\end{array}$ & No analysis necessary \\
\hline $\begin{array}{l}\text { 1. The plant is designed against the } \\
\text { design-basis flood with an exceedance } \\
\text { probability of } 10^{-4} \text { per year } \\
\text { 2. Design with permanent protection } \\
\text { measures } \\
\text { 3. Shut down of the plant according to the } \\
\text { instructions of the operation manual at } \\
\text { a specified water level which is } \\
\text { significantly below the level } \\
\text { 4. Conditional probability for water } \\
\text { impact in case of the design-basis } \\
\text { flood less than } 10^{-2}\end{array}$ & $\begin{array}{l}\text { Determination of possible water } \\
\text { paths in relevant structures and } \\
\text { estimation of the conditional } \\
\text { probability for water impact in } \\
\text { case of the design-basis flood }\end{array}$ \\
\hline Other design & $\begin{array}{l}\text { Determination of the exceedance } \\
\text { for the design-basis flood of the } \\
\text { plant up to a value of }>10^{-4} \text { per } \\
\text { year, detailed event sequence } \\
\text { considerations including the } \\
\text { quantification of core damage } \\
\text { frequency }\end{array}$ \\
\hline
\end{tabular}


For river sites with tidal influences, an extreme flood event - tide combined with storm water level set-up - must be assumed.

Therefore, it is necessary to determine statistically the storm-tide water level with an exceeding frequency of $10^{-2} / \mathrm{a}$ plus a site-specific addend. In conclusions, a storm-tide must be covered with an exceeding frequency of $10^{-4} / \mathrm{a}$.

In the context of the analysis, design-basis flood is that particular flood event on which the flood protection of the plant is based, specifically with regard to meeting the safety objectives. The permanent flood protection is that flood protection which is effective at all times (e.g. protection by floodsafe enclosure, by structural seals). The loads due to the design-basis flood must be combined with other loads such as a operational loads, earth thrust, wind load, static water pressure due to the design water level, streaming water, waves, upswing, flotsam, ice pressure.

\section{Steps of the external flooding analysis}

The probabilistic safety assessment of external flooding can be distinguished into four main steps:

- hazard analysis of the site,

- check that starting from an assumed water level of the plant which is equivalent with the design-basis flood, the non-availability of safety functions for the electrical energy supply and for the residual heat removal in a time schedule of five days for river sites and one day for tidal sites is less than $10^{-2}$,

- analysis of the event sequence and quantification of the contributions to the total frequency of core damage states,

- conduct of an uncertainty analysis.

\section{Determination of storm tide water levels with a probability value of $10^{-4} / \mathrm{a}$}

The flood protection for nuclear power plants in accordance with (Berg and Winter, 2009) presumes a flood event with a probability value ( $\mathrm{p}$-value) of $10^{-4} / \mathrm{a}$, i.e. an extremely seldom flood event. Depending on whether the site is located on inland waters or on coasts with or without tidal waters, different procedures are required for determining the design-basis water level in the vicinity of the plant components to be protected and in the vicinity of the protective structures of the nuclear power plant.

On the basis of the storm tide water level, the corresponding site specific water level in the vicinity of the plant components to be protected and the 
protective structures of the nuclear power plant shall be determined, e.g. by hydraulics calculations.

The storm tide water levels for nuclear power plants on coastal sites and sites on tidal waters shall normally be derived employing the following statistical extrapolation procedure. The water level for a storm tide with a probability factor of $10^{-4} / \mathrm{a}, \mathrm{SFWH}_{\left(10^{-4}\right)}$, shall be determined as the sum of a base value, $\mathrm{BHWH}_{\left(10^{-2}\right)}$, and an extrapolation difference, ED, as follows:

$$
\mathrm{SFWH}_{\left(10^{-4}\right)}=\mathrm{BHWH}_{\left(10^{-2}\right)}+\mathrm{ED}
$$

where

$\mathrm{BHWH}_{\left(10^{-2}\right)}$ : base value of the water level for a storm tide with a probability value of $10^{-2} / \mathrm{a}$ at the site,

ED: extrapolation difference representing the water level difference between the water level of a storm tide with a probability value of $10^{-4} / \mathrm{a}$ and the base value.

The base value, $\mathrm{BHWH}_{\left(10^{-2}\right)}$, shall be determined on the basis of a quantitative statistical extreme-value analysis taking into consideration the relevant parameters (DVWK, 1999).

The base value can be determined employing suitable statistical procedures, because

- the spread of the base values, $B H W H_{\left(10^{-2}\right)}$, is relatively small due to the usually extensive and high quality water-level time series available for coasts and tidal waters,

- the $\mathrm{BHWH}_{\left(10^{-2}\right)}$ water level as a function of the observation duration of the individual time series still is partly in the interpolation region or in the near extrapolation region,

- the $\mathrm{BHWH}_{\left(10^{-2}\right)}$ water level is assured by extensive investigations and is verifiable by physical as well as numerical models.

The water-level data shall be homogenized considering that the storm-tide water levels are dependent on the development of the water level at the coast - especially the secular rise of the sea level - as well as on the anthropogenic changes to the tidal waters.

The extrapolation difference for coasts or for the mouths of tidal rivers shall be determined. Additional information on investigations regarding stormflood water levels with very small exceedance probability is provided in (Jensen, et al., 2007; Jensen, et al., 2008). 


\section{Results of a sensitivity study for a tsunami in the German north sea}

PSA regulations consider extreme events of recurrence intervals of 10000 years. Beside the frequently occurring extreme storm surges, also other events are to be considered. One example is the possible impact of a tsunami type of event.

Geotechnical records give evidence for three tsunamis in the North Sea between 8000 and 1500 years ago (Bondevik, 2005). One well explored source region is the Storegga slide, which was released approximately 8100 cal years bp (Løvholt, 2005).

In the framework of a dedicated study on behalf of BfS, a numerical model was applied by the Center of Marine Environmental Sciences (MARUM) of University of Bremen to simulate the propagation and development of extreme waves in the North Sea towards the German Bight.

In a hydrodynamic numerical model of the European continental shelf sea based on the implicit finite differences modelling system Delft3d-Flow (WL Delft Hydraulics, 2006), the depth-averaged shallow water equations are solved on a spherical grid (Diesing, et al., 2006). This grid covers the region between W13/N48 and E13/N62 with a resolution of 2.5 nautical miles $\left(1 / 24^{\circ}\right)$ in the latitudinal and 3.75 nautical miles $\left(1 / 16^{\circ}\right)$ in the longitudinal direction in discrete time-stepping (Figure 1).

For the study discussed in the following the propagation of an extreme wave event (tsunami) initiated by a hypothetical slide at the continental margin off the Norwegian continental margin has been simulated. Soliton waves were prescribed as water level boundary conditions at the northern open sea boundary of the model.

As the real height of a possible wave cannot be assessed, a range of different wave heights were tested. Simulations show the propagation of the wave across the model domain, considering uniform mean sea level as initial surface elevation condition: After entering the North Sea through the northern boundary, the wave is partly deflected towards the West, because of Coriolis force effects, and partly moves in southern direction through the Norwegian deep. The deflected wave then approaches the British East coast and partly reflects back into the North Sea. Here the primary wave and the reflected wave super-impose into complex patterns. It takes about 8.5 hours for the first wave to reach the German Bight which allows to take precautionary temporary technical measures. 


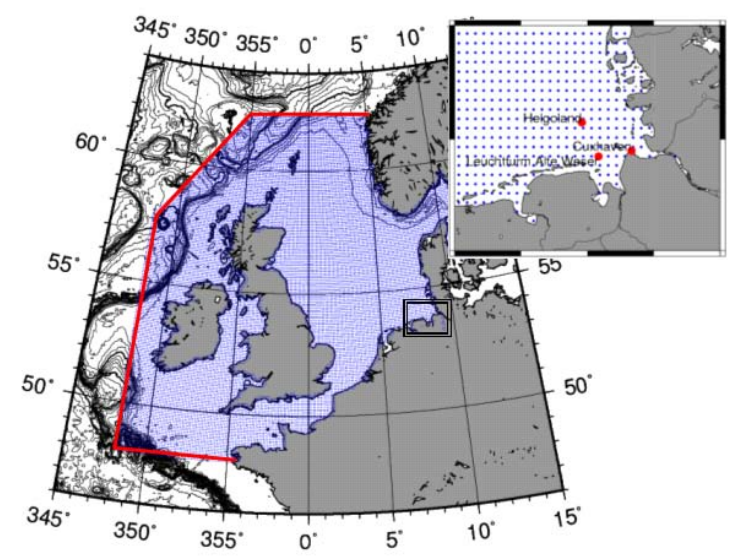

Fig. 1 Domain of interest: Model grid nodes are indicated as blue dots.

The red line denotes the position of open model boundaries.

Tidal gauge stations are chosen for further analysis

The characteristics of the wave triggered by the ancient Storegga event were simulated and described in (Bondevik, 2005). Considering their calculated wave height of 3 meters at the Northern boundary of the model, results in maximum deviations of about 0.5 to $0.7 \mathrm{~m}$ at the tidal gauges in the German Bight.

In contrast to the simulations described above, the natural hydrodynamics of the North Sea are driven by tidal and meteorological forcing. Thus the super-position of the extreme wave with the astronomical tidal conditions of the North Sea has been simulated. The results of these simulations are shown in Figure 2.

Although non-linear effects are obviously present, generally a linear superposition of tidal elevation and extreme wave dimensions based on uniform mean sea level seem to be possible. It is noted that in the German Bight the transformed extreme wave is of much smaller height than the astronomical tidal signal:

The effect of an extreme wave at the gauges Helgoland and Cuxhaven results in less than $10 \%$ of the tidal range and only one fifth of the expected surface elevation of a light storm flood, as defined by German hydrographic agencies.

Similarly at gauge "Lighthouse Alte Weser", the extreme wave is damped to $0.55 \mathrm{~m}$, which is about 17 percent of the tidal range and less than one third of a light storm flood. 


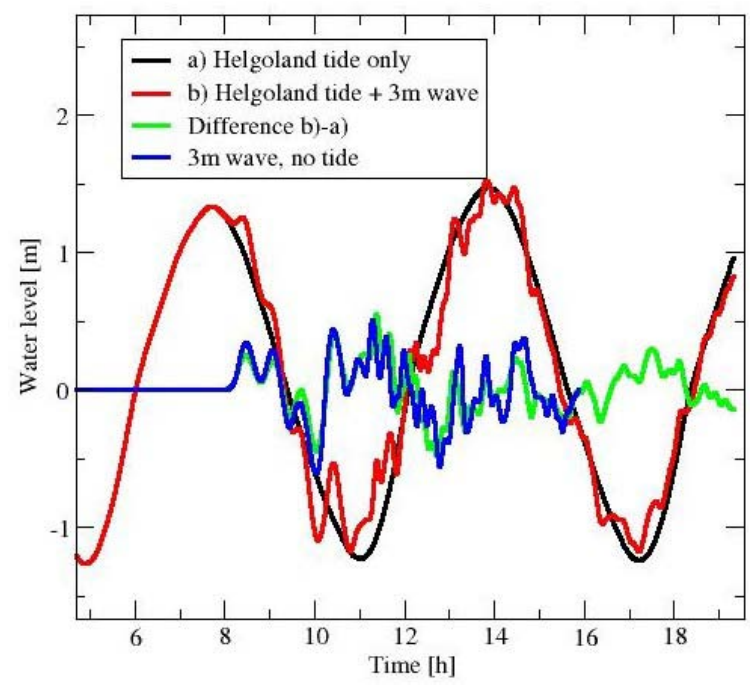

Fig. 2 Superposition of tides and extreme wave signal in the German Bight

Considering the natural hydrodynamic conditions as tides and storm surges of the German Bight, the modelled impact of an extreme event that could be triggered by mass slide events at the northern continental margin, seems negligible.

\section{Extreme Low Water Levels}

To the category "Low Water Level" belong events like small river water conditions or very low tide. They arise either with long dry periods or with strongly off-coast hoist. Usually such climatic conditions are foreseeable during a relatively long period. From this it can be derived that such events have generally no considerable meaning in terms of safety for nuclear power plants, since early counter measures are started, like e.g. the shut down of the plant or to ensure the cooling water supply. For this category accordingly the evaluation of the international operational experience in (Krauß and Thuma, 2008) exhibits only few events with relevance in terms of safety.

Typical effect paths for NPPs at tidal sites are very low tides in connection with strong off-coast hoists, e.g. after flood and storm. This can lead to disturbed inlet conditions for the main cooling water or the reserve emergency cooling system. Thus observed at the NPP Borselle (22.01.1984, Netherlands), as well as at the plant Unterweser (28.01.1993, Germany). In terms of safety in general such events have minor relevance, because 
usually only restrictions on operational systems or non-availabilities of safety-related sub-systems to be observed. In addition, the evaluation of the international operational experience also shows that flood events are reported about seven times more than low water events (Krauß and Thuma, 2008).

\section{Concluding remarks}

The approach for a probabilistic assessment of external hazards including flooding, to be applied within comprehensive safety reviews of NPP in Germany, starts with a screening process which should not be too conservative so that the number of scenarios and buildings remains manageable for the detailed quantitative analysis. However, it has to be ensured that all relevant areas are investigated within the quantitative analysis.

For those areas which have not been screened out or where a coarse meshed analysis is not sufficient it is compulsory to perform a quantitative analysis as a second step. Finally, the frequency of initiating events induced by the respective hazard, the main contributors and the calculated core damage frequency are determined.

On international level, as already mentioned earlier, there exist some standards and guidelines (IAEA, 2003; ANS, 2007), but they are on a very general level and do not allow to perform a PSA of external flooding in a comparable manner for different plants. Moreover a full scope PSA for external flooding of a nuclear power plant is not available to date.

It should be underlined that the probabilistic assessment of external hazards, although an important part of PSA, has not yet achieved the same level of methodological maturity as being typical for other disciplines of PSA. However, boundary conditions for performing the probabilistic safety assessment of external flooding for inland river floods are described, e.g., in (HSK, 2009).

As explained the determination of the occurrence frequencies is done by an analysis of observed water level data based on extreme value statistics where. not only statements of the actual occurrence frequencies are required but also for future time horizons. The common statistical methods postulate a stationary behaviour (no changes through time) of the water level data, which needs to be analysed. However, in the context of climate change this assumption might not longer be applicable. If a significant non-stationary behaviour of the water level data exists, the common statistical stationary methods may not be used any more. Either this stationary behaviour has to 
be removed or need to be integrated directly into the extreme value analysis. A first attempt is provided in (Mudersbach, 2009).

Furthermore, the combination of the components wave crest, storm surge and tidal level is not straightforward and depends on the conditions of the location under consideration. Therefore, a Monte Carlo approach has been developed to joint the probability of these components (Fox, 2009).

\section{References}

1. American Nuclear Society (ANS): External Events in PRA Methodology. ANS/ANS 58.21-2007.

2. Berg, H.-P., Görtz, R.: Probabilistic Safety Assessment of External Flooding of Nuclear Power Plants. Proceedings of the European Safety and Reliability Conference 2006, Estoril, Portugal, Safety and Reliability for Managing Risk, Vol. 2, Taylor \& Francis, London, p. 1341 - 1346, 2006.

3. Berg, H.P., Görtz, R. Fröhmel, T., Winter, C.: Probabilistic Safety Assessment of External Flooding Protection for Nuclear Power Plants in Germany, Journal of Power and Energy Systems, Vol 2, No. 2, p. $734-743,2008$.

4. Berg, H.P., Winter, C.: Analysis of external flooding and tsunamis for nuclear power plants at tidal rivers. Kerntechnik Vol. 74, No 3, p. 132 $-139,2009$.

5. Bondevik, S., Løvholt, F., Harbitz, C.B., Mangerud, J., Dawson, A.G.; Svendsen, J.I.: The Storegga Slide Tsunami - Comparing Field Observations with Numerical Simulations. Marine and Petroleum Geology, Vol. 22, p. 195-208, 2005.

6. Deutscher Verband für Wasserwirtschaft und Kulturbau (DVWK): Statistical Analysis of Peak Level Water Runoffs (Statistische Analyse von Hochwasserabflüssen). DVWK-Merkblatt 251, 1999.

7. Diesing, M., Winter, C., Kubicki, A. and Schwarzer, K.: Decadal scale stability of sorted bedforms, German Bight, south-eastern North Sea. Continental Shelf Research, Vol. 26, p. 902-916, 2006.

8. Facharbeitskreis Probabilistische Sicherheitsanalyse für Kernkraftwerke (FAK PSA): Methods for PSA for NPPS (Methoden zur probabilistischen Sicherheitsanalyse für Kernkraftwerke, Stand: August 2005). BfS-SCHR - 37/05, Salzgitter, Oktober 2005.

9. Fox, J.P. A Monte Carlo Approach to Joint Probability of Wave, Tide and Surge in Extreme Water Level Calculations. Health and Safety Executive, Research Report 740, October 2009. 
10. Hauptabteilung für die Sicherheit von Kernanlagen (HSK): Probabilistic Safety Analysis (PSA): Quality and Scope. Guideline for Swiss Nuclear Installations, ENSI-A-05/e, March 2009.

11. International Atomic Energy Agency: Flood Hazard for Nuclear Power Plants on Coastal and River Sites. Safety Guide, No. NS-G-3.5, Vienna, December 2003.

12. Jensen, J. et. al.: New Procedures for the Assessment of Rare Water Levels from Storm Floods (Neue Verfahren zur Abschätzung von seltenen Sturmflutwasserständen), HANSA, Vol. 140, Nr. 11, p. 68-79, 2003.

13. Jensen, J., Meiswinkel, R., Barg, G., Frank, T., Mudersbach, Ch.: Hochwasserschutz - Sturmflutwasserstand und Wellenauflauf im Küsten- und Ästuarbereich. Tagungsbericht Jahrestagung Kerntechnik 2008, p. 317-320, 2008.

14. Jensen, J., Mudersbach, Ch., Müller-Navarra, S., Bork, I., Koziar, Ch., Renner, V.: Modellgestützte Untersuchungen zu Sturmfluten mit sehr geringen Eintrittswahrscheinlichkeiten an der Deutschen Nordseeküste. Die Küste, Heft 71, 2007.

15. Kerntechnischer Ausschuss: Flood Protection of NPP (Schutz von Kernkraftwerken gegen Hochwasser). KTA 2207, November 2004.

16. Kleeberg, H.-B., Schumann, A. H.: Derivation of Water Runoffs with Small Exceedance Frequencies (Ableitung von Bemessungsabflüssen kleiner Überschreitungswahrscheinlichkeiten). Wasserwirtschaft, Vol 21, Nr. 2, p. $90-95,2001$.

17. Knochenhauer, M., Lonker, P.: Guidance for External Event Analysis. SKI-Report 02:27, February 2003.

18. Krauß, M. ; Thuma, G: Untersuchungen zu extremen Wetterereignissen und Witterungsbedingungen. Gesellschaft für Anlagen- und Reaktorsicherheit (GRS) mbH, GRS-A-3426, September 2008.

19. Løvholt, F., Harbitz, C.B. Haugen, K.B.: A Parametric Study of Tsunamis Generated by Submarine Slides in the Ormen Lange/Storegga Area off Western Norway. Marine and Petroleum Geology, Vol. 22, p. 219-231, 2005.

20. Mudersbach, Ch. Untersuchungen zur Ermittlung von hydrologischen Bemessungsgrößen mit Verfahren der instationären Extremwertstatistik. PhD Thesis, Oktober 2009.

21. WL Delft Hydraulics: Delft3d-FLOW Simulation of multi-dimensional hydrodynamic flows and transport phenomena, including sediments. User Manual, Delft, 2006. 